\title{
Forage herbs improve mineral composition of grassland herbage
}

\author{
K. Pirhofer-Walzl*, K. Søegaard†, H. Høgh-Jensen‡, J. Eriksen†, M. A. Sanderson§, \\ J. Rasmussent and J. Rasmussen* \\ *Department of Agriculture and Ecology, Faculty of Life Sciences, University of Copenhagen, Taastrup, Denmark, \\ tDepartment of Agroecology and Environment, Faculty of Agricultural Sciences, Aarhus University, Tjele, \\ Denmark, ¥Faculty of Science and Technology, Department of Policy Analysis, Aarhus University, Roskilde, \\ Denmark, and §USDA-ARS Northern Great Plains Research Laboratory, Mandan, ND, USA
}

\begin{abstract}
Provision of an adequate mineral supply in the diets of ruminants fed mainly on grassland herbage can present a challenge if mineral concentrations are suboptimal for animal nutrition. Forage herbs may be included in grassland seed mixtures to improve herbage mineral content, although there is limited information about mineral concentrations in forage herbs. To determine whether herbs have greater macro- and micromineral concentrations than forage legumes and grasses, we conducted a 2-year experiment on a loamy-sand site in Denmark sown with a multi-species mixture comprised of three functional groups (grasses, legumes and herbs). Herb species included chicory (Cichorium intybus L.), plantain (Plantago lanceolata L.), caraway (Carum carvi L.) and salad burnet (Sanguisorba minor L.). We also investigated the effect of slurry application on the macro- and micromineral concentration of grasses, legumes and herbs. In general, herbs had greater concentrations of the macrominerals $\mathrm{P}, \mathrm{Mg}, \mathrm{K}$ and $\mathrm{S}$ and the microminerals $\mathrm{Zn}$ and $\mathrm{B}$ than grasses and legumes. Slurry application indirectly decreased $\mathrm{Ca}, \mathrm{S}$, $\mathrm{Cu}$ and $\mathrm{B}$ concentrations of total herbage because of an increase in the proportion of mineral-poor grasses. Our study indicates that including herbs in forage mixtures is an effective way of increasing mineral concentrations in herbage.
\end{abstract}

Keywords: herbs, forage quality, dairy cows, functional plant groups, grass-clover swards, slurry

Correspondence to: Karin Pirhofer-Walzl, Department of Agriculture and Ecology, Faculty of Life Sciences, University of Copenhagen, Højbakkegaard Allé 9, 2630 Taastrup, Denmark.

E-mail: kpw@life.ku.dk

Received 7 September 2010; revised 2 March 2011

\section{Introduction}

Grassland covers about $40 \%$ of the agricultural area in Europe (European Commission, 2006) and it supplies most of the feed used by cattle and other ruminants. Among the various constituents of herbage quality that are important for ruminants is the need for sufficient amounts of minerals in the diet to ensure good health and performance (Underwood and Suttle, 1999). However, it is a challenge to manage the mineral supply of ruminants fed on grassland, because mineral concentrations in the herbage are influenced by a number of factors including species composition of the sward (Kuusela, 2006), time of the year (Høgh-Jensen et al., 2006) and fertilization (Soder and Stout, 2003).

The use of mineral supplementation is allowed in both conventional and organic livestock production systems to ensure that animal health requirements are met (European Commission, 2010; Danish Plant Directorate, 2010). To adhere to organic principles, however, an organic production system should be based on low external inputs and ecological processes adapted to local conditions (IFOAM, 2005; Weller and Bowling, 2007). Hence, options to decrease the dependency on external mineral supplementation have special relevance in organic agriculture.

In temporary grasslands, sown plant species comprise three broad functional groups: grasses, forage legumes and forage herbs. Many conventional (non-organic) grasslands in Europe are sown with relatively simple grass-seed mixtures, sometimes monocultures, whereas organic grasslands are often sown with seed mixtures comprising multiple functional groups, either as grasslegume mixtures or multi-species mixtures that include forage herbs. In temporary organic grasslands, grasslegume mixtures are commonly used because of their ability to be nitrogen self-sufficient and an economic source of nutritious forage legumes (Whitehead, 2000). There are a number of dicotyledonous plant species (i.e. herbs) that occur naturally in pastures or which may be 
included in sown mixtures (Foster, 1988; Smidt and Brimer, 2005). These species can be mineral rich (Foster, 1988; Wilman and Derrick, 1994; Fisher et al., 1996; Whitehead, 2000; Sanderson et al., 2003). Nonetheless, knowledge is scarce about the mineral content of forage herbs (Smidt and Brimer, 2005), and there is a need to understand the mineral contribution of herbs as a botanical component of sustainable grasslands.

We investigated the mineral content of several forage herbs to evaluate whether herbs could increase mineral concentrations in multi-species herbage and thereby decrease the need for external mineral supplementation. We hypothesized that (i) herbs grown in a grass-legume-herb mixture have greater mineral concentrations than grasses and legumes, and (ii) cattle slurry application affects the mineral composition of grasses, legumes and herbs, because of the addition of minerals in the slurry. Forage herbs were grown in a multi-species mixture, because plant species can interact differently with each other when grown in a mixture than when grown in monoculture (Casler et al., 1987).

\section{Materials and methods}

\section{Experimental site and weather conditions}

A multi-species grassland mixture was established as a part of an organic crop rotation for dairy cows at the Research Farm Foulumgaard, Aarhus University, in the central part of Jutland, Denmark $\left(9^{\circ} 34^{\prime} \mathrm{E}, 56^{\circ} 29^{\prime} \mathrm{N}\right)$. The crop rotation had been managed according to EU organic farming standards since 1987. The sequence of crops was as follows: (i) barley (Hordeum vulgare L.); (ii) perennial ryegrass-white clover (Lolium perenne L.-Trifolium repens L.); (iii) grass-white clover-barley wholecrop; (iv) oat (Avena sativa L.); (v) maize (Zea mays L.). The multi-species mixture was undersown with spring barley in 2006; the cover crop was harvested at maturity in August 2006. Mineral concentrations in the herbs were determined in 2007 and 2008.

The loamy-sand soil, a typic Hapludult (Soil Survey Staff, 1998), had a pH of 5.9 and contained $7.7 \%$ clay, $10 \%$ silt, $48 \%$ fine sand, $33 \%$ coarse sand, $1 \cdot 6 \%$ carbon, $60 \mathrm{mg} \mathrm{kg}^{-1}$ exchangeable $\mathrm{K}$ and $21 \mathrm{mg} \mathrm{kg}^{-1}$ extractable $\mathrm{P}$ in the $0-15 \mathrm{~cm}$ layer. It was developed on moraine material from the Weichselian glacial age. The clay fraction was dominated by illite and smectite, and the silt and sand fractions by $\mathrm{Ca}-\mathrm{Na}$ - and $\mathrm{K}$-feldspars in all soil horizons to $1.8 \mathrm{~m}$ depth (Møberg and Dissing, 1986).

Means of monthly air temperatures from April to October in 2007 and 2008 varied between 7 and $17^{\circ} \mathrm{C}$ and growing season means were similar in 2007 $\left(12 \cdot 3^{\circ} \mathrm{C}\right)$ and $2008\left(12 \cdot 4^{\circ} \mathrm{C}\right)$. Means of monthly rainfall from April to October in both years varied between 6 and $142 \mathrm{~mm}$, and total growing season rainfall was $396 \mathrm{~mm}$ in 2007 and $452 \mathrm{~mm}$ in 2008.

\section{Grassland mixture and fertilization treatment}

The experiment comprised plots of $45 \mathrm{~m}^{2}$, with and without slurry application, and with two replicates of each treatment. The multi-species grassland mixture was undersown on 4 May 2006 with spring barley (350 plants per $\mathrm{m}^{2}$ drilled). The barley was harvested at maturity on 9 August 2006.

The multi-species mixture included twelve plant species from three functional groups. It consisted of two grass species, five forage legumes and five nonlegume forage dicots (subsequently described as herbs). Grasses comprised 0.59 of the total seed weight, legumes $0 \cdot 26$ and herbs $0 \cdot 15$. Grasses included festulolium ( $x$ Festulolium with Lolium multiflorum $\mathrm{L}$. and Festuca pratensis L. as parents: 0.31 of the total seed weight) and perennial ryegrass (Lolium perenne L: $0 \cdot 28$ ); legumes included white clover (Trifolium repens L: 0.05), red clover (Trifolium pratense L. cv. Rajah: 0.01), lucerne (Medicago sativa L. cv. Pondus: 0.15), birdsfoot trefoil (Lotus corniculatus L. cv. Lotanova: 0.02) and sainfoin (Onobrychis viciifolia L.: 0.03); and herbs included chicory (Cichorium intybus L. cv. Spadona: 0.03), plantain (Plantago lanceolata L.: 0.03), caraway (Carum carvi L. cv. Sylvia: 0.03), salad burnet (Sanguisorba minor L.: 0.03) and chervil (Anthriscus cerefolium L.: 0.03). Chervil and sainfoin did not establish and were thus not taken into account in the experiment.

One half of the plots received NPK in the form of cattle slurry in amounts based on an analysis to provide $\mathrm{N}$ equivalent to $200 \mathrm{~kg} \mathrm{~N} \mathrm{ha}^{-1}$ split between applications in the spring and after the first cut in 2007 and 2008 (200N plots). The cattle slurry contained $6 \cdot 8 \%$ dry matter in 2007 and $3 \cdot 8 \%$ dry matter in 2008 (Table 1). No slurry was applied on the other half of the plots $(0 \mathrm{~N}$ plots). Potassium-vinasse fertilizer, an organic fertilizer accepted by the Danish Plant Directorate (Danish Plant Directorate, 2010), was supplied to avoid potassium deficiency, which has often occurred without K fertilization at this site (Askegaard et al., 2003). The crop rotation at this site has historically always been amended with applications of cattle manure until the slurry treatment imposed as part of this study. Plots were not irrigated during either of the two growing seasons.

\section{Sampling and analysis}

Herbage was harvested with a Haldrup plot harvester (J Haldrup A/S, Loegstoer, Denmark) from a subplot of $10 \mathrm{~m}^{2}$ on four occasions during each growing season in 
Table I Nitrogen (N), phosphorus (P) and potassium (K) application to multi-species grassland in form of cattle slurry for $200 \mathrm{~N}\left(200 \mathrm{~kg} \mathrm{~N} \mathrm{ha}^{-1}\right)$ and $0 \mathrm{~N}\left(0 \mathrm{~kg} \mathrm{~N} \mathrm{ha}^{-1}\right)$ plots in 2007 and 2008 .

\begin{tabular}{|c|c|c|c|c|c|}
\hline & \multirow{2}{*}{$\begin{array}{c}\mathbf{0 N} \\
\begin{array}{c}\text { Additional } \\
\mathrm{K}^{*}\end{array}\end{array}$} & \multicolumn{4}{|c|}{$200 N$} \\
\hline & & $\mathbf{N}$ & $\frac{\mathrm{P}}{\mathrm{kg} \mathrm{ha^{-1 }}}$ & $\mathbf{K}$ & $\begin{array}{c}\text { Additional } \\
\qquad \mathbf{K}^{*}\end{array}$ \\
\hline \multicolumn{6}{|l|}{2007} \\
\hline Spring & 100 & 100 & 21 & 123 & - \\
\hline Summer & 100 & 100 & 24 & 96 & 100 \\
\hline Total & 200 & 200 & 45 & 219 & 100 \\
\hline \multicolumn{6}{|l|}{2008} \\
\hline Spring & 100 & 100 & 18 & 88 & - \\
\hline Summer & 150 & 100 & 19 & 96 & 100 \\
\hline Total & 250 & 200 & 37 & 184 & 100 \\
\hline
\end{tabular}

*Additional $\mathrm{K}$ was added as potassium-vinasse fertilizer to avoid deficiency. The amount was increased in 2008, based on soil analysis, to maintain soil $\mathrm{K}$ levels.

2007 and 2008. The sward was mown to a residual height of $8 \mathrm{~cm}$. A subsample of approximately $400 \mathrm{~g}$ of the total herbage was taken from the first and third cut in both years (23 May and 15 August in 2007, 26 May and 22 August in 2008), separated into individual species and dried in a forced draught oven at $80^{\circ} \mathrm{C}$ to constant dry weight. The two grass species, perennial ryegrass and festulolium, were pooled. All unsown species were combined, but not analysed for mineral concentrations. The samples were ground in a Christy hammermill (Tekemas, Rødovre, Denmark) to pass a $0 \cdot 8-\mathrm{mm}$ sieve. Subsamples were digested with nitric acid $(69-70 \%)$ and hydrogen peroxide $(30 \%)$ in a ModBlock at $95^{\circ} \mathrm{C}$ following the EPA (Environmental Protection Agency, USA) method 3050B (related to EPA 6020) (Husted et al., 2004). Calcium (Ca), phosphorus $(\mathrm{P})$, magnesium $(\mathrm{Mg})$, potassium $(\mathrm{K})$, sodium $(\mathrm{Na})$, sulphur $(\mathrm{S})$, copper $(\mathrm{Cu})$, iron $(\mathrm{Fe})$, manganese $(\mathrm{Mn})$, zinc (Zn), molybdenum (Mo), chromium (Cr), boron (B) and aluminium (Al) concentrations were analysed by Inductively Coupled Plasma Optical Emission Spectroscopy (Perkin Elmer Optima 4300 DV ICP-OES; Perkin Elmer Life and Analytical Sciences, Inc., Boston, MA, USA) using instrumental settings as described by Hansen et al. (2009). Total nitrogen (N) was analysed with an ANCA-SL Elemental Analyser coupled to a 2020 Tracermass Mass Spectrometer (SerCon Ltd., Crewe, UK). The aluminium concentration was used solely as a quality control for the sample and was not included in the statistical analysis. Aluminium results obtained in the current study were within the common range for higher plants (data not shown; Kabata-Pendias and Pendias, 2000).

\section{Calculations and statistical methods}

Mineral concentrations, herbage yields and the botanical composition (proportion of the three functional groups) were analysed statistically by analysis of variance with the open-source statistical program R ( R Development Core Team, 2010). A four-way mixed factorial ANova model was used with block (replicate) as a random factor and fertilization, cut, year and functional group as fixed factors. K, P, S and Na concentrations were $\log$ transformed before analysis based on the distribution of the residuals. $\mathrm{Na}, \mathrm{Mo}$ and Cr data were available only for 2008, which excluded year as a factor in the statistical analysis. Multiple comparisons of means for yield and the effect of functional group on the mineral concentrations were calculated using the Waller-Duncan test. Mineral concentrations in total harvested herbage were calculated for each mineral by taking the proportion of each plant species into account.

\section{Results}

\section{Herbage yield}

Herbage yield was greater in 2008 than in 2007 $(P<0 \cdot 05$, Figure 1$)$ and decreased from the first to the fourth cut with the exception of the $0 \mathrm{~N}$ plots in the second and third cuts of 2007, which were the same (Figure 1). Slurry application increased herbage yield of the multi-species mixture at the first and second

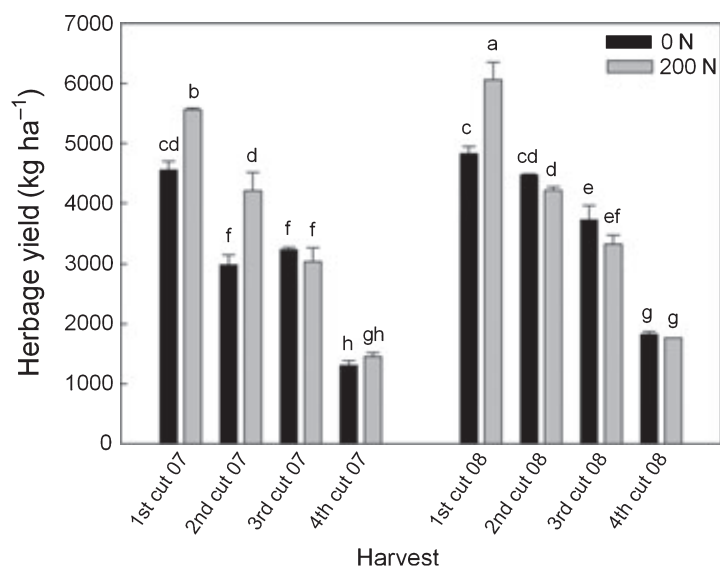

Figure I Mean herbage production $\left(\mathrm{kg} \mathrm{DM} \mathrm{ha}^{-1}\right)$ from a nine-species-sown grassland sward receiving either $0 \mathrm{~kg} \mathrm{~N} \mathrm{ha}{ }^{-1}(0 \mathrm{~N})$ or $200 \mathrm{~kg} \mathrm{~N} \mathrm{ha}^{-1}(200 \mathrm{~N})$ as slurry, recorded at the first, second, third and fourth cuts in 2007 and 2008. Values are means \pm s.e. $(n=2)$. Different lower case letters show significant difference $(P<0.05)$. 
cuts in 2007 and at the first cut in $2008(P<0.05$, Figure 1).

\section{Botanical composition}

The proportions of grasses, legumes and herbs in the mixture varied with the cut $(P<0.001)$, slurry application $(P<0.05)$ and year $(P<0.05)$. Slurry application in early spring strongly stimulated grass growth and reduced the proportion of legumes in the mixture but

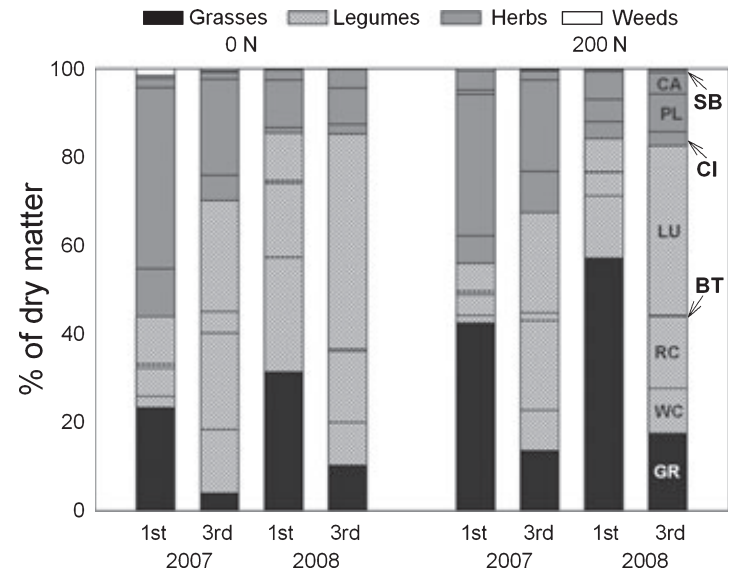

Figure 2 Botanical composition of herbage harvested at the first and third cuts and for the two fertilizer treatments $\left(0 \mathrm{~N}=0 \mathrm{~kg} \mathrm{~N} \mathrm{ha}{ }^{-1}, 200 \mathrm{~N}=200 \mathrm{~kg} \mathrm{~N} \mathrm{ha}{ }^{-1}\right.$ year $^{-1}$ supplied as slurry) in 2007 and 2008. Values are means of replicates $(n=2)$. GR, grasses (all grass species combined); WC, white clover; RC, red clover; BT, birdsfoot trefoil; LU, lucerne; $\mathrm{Cl}$, chicory; PL, plantain; CA, caraway; SB, salad burnet. did not change the proportion of herbs (Figure 2). Grasses and legumes increased as a proportion of the total herbage in both years, whereas the proportion of herbs decreased (Figure 2). The grass proportion decreased from the first to the third cut in both years. In contrast, the proportion of legumes increased from the first to the third cut (Figure 2). Herbs decreased from the first to the third cut in 2007, and there were equal proportions at both cuts in 2008 (Figure 2). Birdsfoot trefoil and salad burnet made only very small contributions to the multi-species mixture in both years.

\section{Macromineral concentrations in functional groups}

For all macromineral concentrations, the three- and four-way interactions were not significant, and the cut $\times$ year interaction was significant only for $\mathrm{N}$ and $\mathrm{Ca}$ (Table 2). Consequently, results are presented in Table 3 as average concentrations for the functional groups. The concentrations of five macrominerals were greater in herbs than grasses or legumes, independent of year and cut (Table 3). P and $\mathrm{K}$ concentrations were greatest in herbs at both cutting dates $(P<0.05)$, and $\mathrm{Ca}, \mathrm{Mg}$ and S concentrations were greater in herbs than in grasses and legumes only at the third cut $(P<0 \cdot 05)$. Legumes had similar ( $\mathrm{Mg}$ and $\mathrm{S}$ at the first cut) or greater ( $\mathrm{Ca}$ at the first cut and $\mathrm{N}$ at both cuts) mineral concentrations than herbs, and they also had the greatest $\mathrm{N}$ concentration $(P<0.05)$. From the first to the third cut, the concentration of macrominerals increased in herbs and grasses but not in legumes (Table 3). Na concentrations were similar in all three functional groups.

Table 2 Analysis of variance with main effects and interaction effects of different factors on mineral concentration (functional group: grass, legume, herb, treat: treatment with and without slurry application, cut: first and third cut, year: 2007 and 2008).

\begin{tabular}{|c|c|c|c|c|c|c|c|c|c|c|c|c|c|c|}
\hline \multirow[b]{2}{*}{ Source of variation } & \multicolumn{14}{|c|}{ Mineral concentration } \\
\hline & $\mathbf{K}$ & Mg & $\mathrm{Ca}$ & $\mathbf{N}$ & $\mathbf{P}$ & $\mathbf{S}$ & $\mathbf{N a}$ & $\mathrm{Zn}$ & $\mathrm{Cu}$ & Mn & $\mathrm{Fe}$ & B & $\mathrm{Cr}$ & Mo \\
\hline Group & $* * *$ & $* * *$ & $* * *$ & $* * *$ & $* * *$ & $* * *$ & NS & $* * *$ & $* * *$ & NS & NS & $* * *$ & $* * *$ & * \\
\hline Treat & NS & NS & NS & NS & NS & $* *$ & NS & * & NS & NS & NS & NS & NS & NS \\
\hline Cut & $* * *$ & $* * *$ & NS & $* * *$ & $* * *$ & $* * *$ & NS & $* * *$ & $* * *$ & NS & NS & $* * *$ & NS & $* * *$ \\
\hline Year & $* * *$ & NS & NS & $* * * *$ & $* * *$ & * & - & $* * *$ & $* * *$ & $* *$ & $* * *$ & NS & - & - \\
\hline Group $\times$ treat & NS & NS & NS & NS & NS & NS & NS & NS & NS & NS & NS & NS & NS & NS \\
\hline Group $\times$ cut & $* * *$ & $* * *$ & $* * *$ & $* * *$ & $* * *$ & $* * *$ & NS & $* * *$ & $* *$ & $* * *$ & $* * *$ & $*$ & $* *$ & $* *$ \\
\hline Group $\times$ year & NS & NS & $* * *$ & $* * *$ & NS & NS & - & $* *$ & NS & NS & $* *$ & NS & - & - \\
\hline Treat $\times$ cut & NS & NS & NS & NS & NS & NS & NS & NS & NS & NS & NS & NS & NS & NS \\
\hline Treat $\times$ year & NS & NS & NS & NS & NS & NS & - & NS & NS & NS & NS & NS & - & - \\
\hline Cut $\times$ year & NS & NS & $* * *$ & $* * *$ & NS & NS & - & $* * *$ & NS & NS & $* *$ & NS & - & - \\
\hline
\end{tabular}

Significance: NS: not significant, ${ }^{*} P>0 \cdot 05, * * P<0 \cdot 01, * * * P<0 \cdot 001$ 
Table 3 Macromineral concentrations in grasses, legumes and herbs (as functional groups) and in nine grassland plant species for the first and third cuts. Values are means of 2 years, two rates of slurry application and two replicates $(n=6)$.

\begin{tabular}{|c|c|c|c|c|c|c|c|c|c|c|c|c|c|c|c|}
\hline \multirow[b]{3}{*}{ Group } & \multirow{2}{*}{$\frac{\text { Macromineral }}{\text { Cut }}$} & \multicolumn{2}{|c|}{$\mathrm{Ca}$} & \multicolumn{2}{|c|}{$\mathbf{P}$} & \multicolumn{2}{|c|}{ Mg } & \multicolumn{2}{|c|}{$\mathbf{K}$} & \multicolumn{2}{|c|}{$\mathbf{N}$} & \multicolumn{2}{|c|}{$\mathrm{Na}$} & \multicolumn{2}{|c|}{$S$} \\
\hline & & lst & $3 r d$ & lst & $3 r d$ & lst & $3 r d$ & 1st & $3 r d$ & 1st & 3rd & 1st & 3rd & 1st & 3rd \\
\hline & Plant species & \multicolumn{14}{|c|}{$\mathrm{g} \mathrm{kg}^{-1}$ dry matter } \\
\hline Grass & Grasses & $3 \cdot 6^{\mathrm{c}}$ & $5 \cdot 7^{\mathrm{c}}$ & $2 \cdot 7^{\mathrm{b}}$ & $5 \cdot 2^{\mathrm{b}}$ & $1 \cdot 3^{\mathrm{b}}$ & $2 \cdot 2^{\mathrm{c}}$ & $24 \cdot 7^{\mathrm{b}}$ & $43 \cdot 2^{\mathrm{a}}$ & $13 \cdot 4^{\mathrm{c}}$ & $26 \cdot 6^{\mathrm{b}}$ & $0 \cdot 9^{\mathrm{a}}$ & $1 \cdot 5^{\mathrm{a}}$ & $1 \cdot 5^{\mathrm{b}}$ & $3 \cdot 8^{\mathrm{b}}$ \\
\hline \multirow[t]{5}{*}{ Legume } & White clover & $21 \cdot 5$ & $17 \cdot 3$ & $2 \cdot 4$ & $3 \cdot 6$ & $2 \cdot 9$ & $3 \cdot 2$ & $25 \cdot 8$ & $29 \cdot 4$ & $32 \cdot 7$ & $34 \cdot 4$ & $1 \cdot 8$ & $2 \cdot 1$ & $2 \cdot 0$ & $2 \cdot 1$ \\
\hline & Red clover & $17 \cdot 2$ & $15 \cdot 8$ & $2 \cdot 2$ & $2 \cdot 8$ & $3 \cdot 8$ & $3 \cdot 8$ & $21 \cdot 6$ & $23 \cdot 6$ & $29 \cdot 2$ & $26 \cdot 9$ & $0 \cdot 4$ & $0 \cdot 6$ & $1 \cdot 6$ & $1 \cdot 7$ \\
\hline & Lucerne & $19 \cdot 2$ & $15 \cdot 4$ & $2 \cdot 4$ & $2 \cdot 7$ & $2 \cdot 8$ & $2 \cdot 6$ & $21 \cdot 2$ & $21 \cdot 1$ & $31 \cdot 1$ & $30 \cdot 1$ & 0.9 & $1 \cdot 0$ & $2 \cdot 0$ & $2 \cdot 7$ \\
\hline & Birdsfoot trefoil & $11 \cdot 4$ & $11 \cdot 2$ & $3 \cdot 0$ & $3 \cdot 0$ & $2 \cdot 6$ & $2 \cdot 5$ & $29 \cdot 3$ & $28 \cdot 6$ & $33 \cdot 2$ & $30 \cdot 2$ & $0 \cdot 3$ & $0 \cdot 5$ & $2 \cdot 5$ & $2 \cdot 3$ \\
\hline & Average & $17 \cdot 3^{\mathrm{a}}$ & $15 \cdot 0^{\mathrm{b}}$ & $2 \cdot 5^{\mathrm{b}}$ & $3 \cdot 0^{c}$ & $3 \cdot 0^{\mathrm{a}}$ & $3 \cdot 0^{\mathrm{b}}$ & $24 \cdot 5^{\mathrm{b}}$ & $25 \cdot 7^{\mathrm{b}}$ & $31 \cdot 6^{\mathrm{a}}$ & $30 \cdot 4^{\mathrm{a}}$ & $0 \cdot 9^{\mathrm{a}}$ & $1 \cdot 1^{a}$ & $2 \cdot 0^{\mathrm{a}}$ & $2 \cdot 2^{\mathrm{c}}$ \\
\hline \multirow[t]{5}{*}{ Herb } & Chicory & $11 \cdot 5$ & $16 \cdot 4$ & 3.9 & $5 \cdot 5$ & $2 \cdot 9$ & $3 \cdot 4$ & $41 \cdot 1$ & $40 \cdot 3$ & $15 \cdot 1$ & $19 \cdot 3$ & $3 \cdot 3$ & $4 \cdot 4$ & $2 \cdot 3$ & $5 \cdot 0$ \\
\hline & Plantain & $12 \cdot 6$ & $18 \cdot 7$ & $3 \cdot 0$ & $4 \cdot 6$ & $2 \cdot 6$ & $2 \cdot 9$ & $28 \cdot 7$ & $31 \cdot 2$ & $15 \cdot 7$ & $16 \cdot 2$ & $0 \cdot 4$ & $0 \cdot 7$ & $2 \cdot 4$ & $4 \cdot 9$ \\
\hline & Caraway & $11 \cdot 8$ & $15 \cdot 0$ & $3 \cdot 6$ & $9 \cdot 9$ & $3 \cdot 1$ & $4 \cdot 3$ & $44 \cdot 5$ & $66 \cdot 5$ & $14 \cdot 5$ & $22 \cdot 3$ & $0 \cdot 1$ & $0 \cdot 1$ & 1.5 & $3 \cdot 4$ \\
\hline & Salad burnet & $17 \cdot 6$ & - & $2 \cdot 8$ & - & $4 \cdot 7$ & - & $19 \cdot 7$ & - & $14 \cdot 5$ & - & $0 \cdot 3$ & - & 1.9 & - \\
\hline & Average & $13 \cdot 4^{\mathrm{b}}$ & $16 \cdot 7^{\mathrm{a}}$ & $3 \cdot 4^{\mathrm{a}}$ & $6 \cdot 7^{\mathrm{a}}$ & $3 \cdot 3^{a}$ & $3.5^{\mathrm{a}}$ & $30 \cdot 5^{a}$ & $46 \cdot 0^{\mathrm{a}}$ & $15 \cdot 0^{\mathrm{b}}$ & $19 \cdot 3^{\mathrm{C}}$ & $1 \cdot 0^{\mathrm{a}}$ & $1 \cdot 7^{\mathrm{a}}$ & $2 \cdot 1^{a}$ & $4 \cdot 4^{\mathrm{a}}$ \\
\hline
\end{tabular}

Different lower case letters in the same column show significant difference $(P<0 \cdot 05)$.

\section{Micromineral concentrations in functional groups}

For all microminerals, the three- and four-way interactions were not significant, and the cut $\times$ year interaction was significant only for $\mathrm{Zn}$ and Fe (Table 2). Consequently, average concentrations for the functional groups are presented in Table 4. Herbs had greater concentrations of $\mathrm{B}$ and $\mathrm{Zn}$ compared with grasses and legumes, but in general there were no clear differences between herbs and legumes.

Herbs and legumes had relatively high concentrations of $\mathrm{Cu}$ at both cuts, whereas $\mathrm{Fe}$ and $\mathrm{Zn}$ concentrations were relatively high at the first cut as was Mo at the third cut (Table 4). Herbs and grasses had greater Mn and $\mathrm{Cr}$ concentrations than legumes at the third cut $(P<0.05)$. There was no difference among the three functional groups for $\mathrm{Mn}$ and Mo at the first cut and Fe

Table 4 Micromineral concentration in grasses, legumes and herbs (as functional groups) and in nine grassland plant species for the first and third cut. Values are means of 2 years, two rates of slurry application and two replicates $(n=6)$.

\begin{tabular}{|c|c|c|c|c|c|c|c|c|c|c|c|c|c|c|c|}
\hline \multirow[b]{3}{*}{ Group } & \multirow{2}{*}{$\frac{\text { Micromineral }}{\text { Cut }}$} & \multicolumn{2}{|c|}{$\mathbf{C u}$} & \multicolumn{2}{|c|}{$\mathrm{Fe}$} & \multicolumn{2}{|c|}{ Mn } & \multicolumn{2}{|c|}{ Zn } & \multicolumn{2}{|c|}{ Mo } & \multicolumn{2}{|c|}{$\mathrm{Cr}$} & \multicolumn{2}{|c|}{ B } \\
\hline & & 1st & $3 r d$ & lst & $3 r d$ & lst & 3rd & lst & 3rd & lst & $3 r d$ & lst & $3 r d$ & lst & 3 rd \\
\hline & Plant species & \multicolumn{14}{|c|}{$\mathrm{mg} \mathrm{kg}^{-1}$ dry matter } \\
\hline Grass & Grasses & $3 \cdot 7^{\mathrm{b}}$ & $8.5^{\mathrm{b}}$ & $50 \cdot 9^{\mathrm{b}}$ & $82 \cdot 3^{\mathrm{a}}$ & $63 \cdot 6^{\mathrm{a}}$ & $82 \cdot 7^{\mathrm{a}}$ & $17 \cdot 7^{\mathrm{b}}$ & $28 \cdot 7^{\mathrm{b}}$ & $1 \cdot 0^{\mathrm{a}}$ & $1.5^{\mathrm{a}}$ & $0 \cdot 2^{\mathrm{c}}$ & $0 \cdot 3^{\mathrm{a}}$ & $3 \cdot 1^{\mathrm{C}}$ & $4 \cdot 7$ \\
\hline \multirow[t]{5}{*}{ Legume } & White clover & $6 \cdot 4$ & $9 \cdot 2$ & $95 \cdot 3$ & $92 \cdot 5$ & $96 \cdot 7$ & $71 \cdot 2$ & $24 \cdot 4$ & $27 \cdot 4$ & $0 \cdot 9$ & $0 \cdot 9$ & $0 \cdot 2$ & $0 \cdot 2$ & $18 \cdot 9$ & $25 \cdot c$ \\
\hline & Red clover & $7 \cdot 3$ & $11 \cdot 0$ & $62 \cdot 3$ & $62 \cdot 0$ & 63.9 & $56 \cdot 2$ & $24 \cdot 2$ & $27 \cdot 1$ & $0 \cdot 8$ & $0 \cdot 7$ & $0 \cdot 2$ & $0 \cdot 2$ & $16 \cdot 9$ & $21 \cdot 8$ \\
\hline & Lucerne & $5 \cdot 8$ & $7 \cdot 4$ & $69 \cdot 8$ & $63 \cdot 1$ & $43 \cdot 5$ & $47 \cdot 7$ & $25 \cdot 0$ & $22 \cdot 9$ & $1 \cdot 4$ & $0 \cdot 3$ & $0 \cdot 2$ & $0 \cdot 2$ & $18 \cdot 8$ & $19 \cdot 6$ \\
\hline & Birdsfoot trefoil & $6 \cdot 2$ & $9 \cdot 0$ & $81 \cdot 4$ & $77 \cdot 6$ & $52 \cdot 4$ & $50 \cdot 5$ & $30 \cdot 8$ & $27 \cdot 7$ & $1 \cdot 7$ & $1 \cdot 1$ & $0 \cdot 2$ & $0 \cdot 2$ & $18 \cdot 3$ & $24 \cdot c$ \\
\hline & Average & $6 \cdot 4^{\mathrm{a}}$ & $9 \cdot 2^{\mathrm{ab}}$ & $77 \cdot 3^{\mathrm{a}}$ & $73 \cdot 8^{\mathrm{a}}$ & $64 \cdot 1^{\mathrm{a}}$ & $56 \cdot 4^{\mathrm{b}}$ & $26 \cdot 0^{a}$ & $26 \cdot 3^{\mathrm{b}}$ & $1 \cdot 2^{\mathrm{a}}$ & $0 \cdot 8^{\mathrm{b}}$ & $0 \cdot 2^{\mathrm{b}}$ & $0 \cdot 2^{\mathrm{b}}$ & $18 \cdot 2^{\mathrm{b}}$ & $22 \cdot 6^{\mathrm{l}}$ \\
\hline \multirow[t]{5}{*}{ Herb } & Chicory & $7 \cdot 0$ & $11 \cdot 5$ & $81 \cdot 0$ & $78 \cdot 0$ & $67 \cdot 9$ & $85 \cdot 7$ & $30 \cdot 0$ & $44 \cdot 9$ & $1 \cdot 1$ & $0 \cdot 4$ & $0 \cdot 3$ & $0 \cdot 3$ & $25 \cdot 2$ & $26 \cdot 5$ \\
\hline & Plantain & $6 \cdot 6$ & $9 \cdot 7$ & $69 \cdot 9$ & $57 \cdot 1$ & $27 \cdot 3$ & $39 \cdot 2$ & $23 \cdot 3$ & $38 \cdot 3$ & $0 \cdot 4$ & $0 \cdot 4$ & $0 \cdot 2$ & $0 \cdot 2$ & $19 \cdot 8$ & $20 \cdot 8$ \\
\hline & Caraway & $5 \cdot 2$ & $8 \cdot 8$ & $74 \cdot 7$ & $83 \cdot 7$ & $59 \cdot 8$ & $93 \cdot 9$ & $22 \cdot 3$ & $39 \cdot 3$ & $1 \cdot 8$ & $0 \cdot 8$ & $0 \cdot 3$ & $0 \cdot 4$ & $29 \cdot 3$ & $31 \cdot 3$ \\
\hline & Salad burnet & $5 \cdot 8$ & - & $70 \cdot 9$ & - & $69 \cdot 8$ & - & $22 \cdot 5$ & - & $1 \cdot 0$ & - & $0 \cdot 2$ & - & $29 \cdot 1$ & \\
\hline & Average & $6 \cdot 2^{\mathrm{a}}$ & $10 \cdot 0^{\mathrm{a}}$ & $74 \cdot 0^{\mathrm{a}}$ & $73 \cdot 0^{\mathrm{a}}$ & $56 \cdot 2^{\mathrm{a}}$ & $72 \cdot 9^{\mathrm{a}}$ & $25 \cdot 4^{\mathrm{a}}$ & $40 \cdot 8^{a}$ & $1 \cdot 1^{\mathrm{a}}$ & $0 \cdot 5^{\mathrm{b}}$ & $0 \cdot 3^{\mathrm{a}}$ & $0 \cdot 3^{\mathrm{a}}$ & $25 \cdot 9^{\mathrm{a}}$ & $26 \cdot 2^{\mathrm{a}}$ \\
\hline
\end{tabular}

Different lower case letters in the same column show significant difference $(P<0 \cdot 05)$. 
at the third cut $(P>0 \cdot 05)$. Cu and B concentrations increased for all three groups from the first to the third cut. In herbs and in grasses, the $\mathrm{Mn}$ and $\mathrm{Zn}$ concentrations increased from the first to the third cut, whereas in legumes they remained the same or decreased (Table 4). All other mineral concentrations remained the same or decreased from the first to the third cut in all three functional groups.

\section{Fertilization}

Fertilization with cattle slurry had no effect on the mineral concentration $\times$ functional group interaction $(P>0.05$; Table 2$)$. Nonetheless, slurry application slightly increased $\mathrm{S}$ and $\mathrm{Zn}$ concentration $(P<0.05$; Table 2). After taking the proportions of the different plant species into account, the concentrations of $\mathrm{Ca}, \mathrm{S}$, $\mathrm{Cu}$ and $\mathrm{B}$ in the total herbage were negatively affected by slurry application (Table 5 ).

\section{Discussion}

Herbs had the greatest concentrations of most of the minerals investigated, followed by legumes and then grasses. Grasses, however, often had greater $\mathrm{Mn}$ and Mo concentrations than legumes and herbs. Fertilization influenced the botanical composition of herbage because slurry application stimulated grass growth. The general finding that herbs contained greater mineral concentrations than grasses was not changed by fertilization with slurry. The concentration of several minerals increased in grasses and herbs from the first to the third cut, but it decreased in legumes. The concentration of most minerals in herbs seems to be relatively unaffected by the environment, because none of the strong environmental factors, fertilization and year, changed the relative proportions between mineral concentrations in the three functional groups.

\section{Functional groups and mineral concentrations}

Mineral acquisition of a plant is regulated partly by the cation exchange sites of plant cell walls, which are more abundant in dicotyledonous plants compared with monocotyledonous plants (Haynes, 1980). This leads to greater concentration of some minerals in legumes and herbs compared with grasses (Marschner, 1995). The results of the present study support the hypothesis that forage herbs have an ability to accumulate a number of minerals. This is in agreement with GarciaCiudad et al. (1997) who showed for a semi-natural grassland in central-western Spain that herbs had greater mineral concentrations than grasses and legumes.

Table 5 The calculated macro- and micromineral concentrations and mineral yield ratios in the total harvested herbage of a grassclover-herb mixture taken at the first and third cuts and for two slurry fertilization treatments $\left(0 \mathrm{~N}=0 \mathrm{~kg} \mathrm{~N} \mathrm{ha}{ }^{-1}\right.$; $200 \mathrm{~N}=200 \mathrm{~kg} \mathrm{~N} \mathrm{ha}^{-1}$ ) in 2007 and 2008.

\begin{tabular}{|c|c|c|c|c|c|c|c|c|c|}
\hline \multirow{3}{*}{$\frac{\text { Year }}{\text { Harvest time }} \frac{\text { Fertilization }}{\text { Fimation }}$} & \multicolumn{4}{|c|}{2007} & \multicolumn{4}{|c|}{2008} & \multirow[b]{3}{*}{ NRC } \\
\hline & \multicolumn{2}{|c|}{ lst cut } & \multicolumn{2}{|c|}{3 rd cut } & \multicolumn{2}{|c|}{ lst cut } & \multicolumn{2}{|c|}{$3 r d$ cut } & \\
\hline & $\mathbf{O N}$ & $200 N$ & $\mathbf{O N}$ & $200 N$ & $\mathbf{O N}$ & $200 \mathrm{~N}$ & $\mathbf{O N}$ & $200 N$ & \\
\hline \multicolumn{10}{|c|}{ Macromineral ( $\mathrm{g} \mathrm{kg}^{-1}$ dry-matter herbage) } \\
\hline K & $23 \cdot 3$ & $23 \cdot 1$ & $25 \cdot 6$ & $26 \cdot 7$ & $28 \cdot 9$ & $28 \cdot 3$ & $34 \cdot 4$ & $31 \cdot 58$ & $10 \cdot 4$ \\
\hline $\mathrm{Mg}$ & 2.5 & $2 \cdot 3$ & $2 \cdot 9$ & $3 \cdot 0$ & $2 \cdot 4$ & $2 \cdot 0$ & $2 \cdot 9$ & $3 \cdot 1$ & 1.9 \\
\hline $\mathrm{Ca}$ & $12 \cdot 2$ & $9 \cdot 3$ & $15 \cdot 2$ & $14 \cdot 5$ & $12 \cdot 3$ & $8 \cdot 4$ & $14 \cdot 0$ & $14 \cdot 7$ & $6 \cdot 1$ \\
\hline $\mathrm{P}$ & $2 \cdot 6$ & $2 \cdot 8$ & $3 \cdot 3$ & $3 \cdot 6$ & $2 \cdot 7$ & $2 \cdot 8$ & $4 \cdot 4$ & $4 \cdot 3$ & $3 \cdot 5$ \\
\hline $\mathrm{N}$ & $18 \cdot 1$ & $16 \cdot 4$ & $23 \cdot 1$ & $21 \cdot 8$ & $23 \cdot 5$ & $17 \cdot 8$ & $29 \cdot 1$ & $31 \cdot 1$ & \\
\hline $\mathrm{Na}$ & - & - & - & - & $0 \cdot 9$ & $1 \cdot 1$ & $1 \cdot 2$ & $1 \cdot 2$ & $2 \cdot 3$ \\
\hline S & $2 \cdot 1$ & $1 \cdot 6$ & $3 \cdot 0$ & $2 \cdot 9$ & 1.9 & $1 \cdot 6$ & $3 \cdot 1$ & $3 \cdot 1$ & $2 \cdot 0$ \\
\hline \multicolumn{10}{|c|}{ Micromineral (mg kg ${ }^{-1}$ dry-matter herbage) } \\
\hline $\mathrm{Zn}$ & $18 \cdot 2$ & $18 \cdot 3$ & $21 \cdot 1$ & $22 \cdot 5$ & $25 \cdot 7$ & $19 \cdot 1$ & $30 \cdot 1$ & $38 \cdot 4$ & 48 \\
\hline $\mathrm{Cu}$ & $5 \cdot 1$ & $4 \cdot 9$ & $8 \cdot 8$ & $8 \cdot 3$ & $5 \cdot 87$ & $5 \cdot 2$ & $9 \cdot 7$ & $9 \cdot 4$ & 11 \\
\hline $\mathrm{Mn}$ & $53 \cdot 9$ & $49 \cdot 2$ & $60 \cdot 3$ & $60 \cdot 9$ & $56 \cdot 4$ & $59 \cdot 1$ & $56 \cdot 9$ & $56 \cdot 8$ & 14 \\
\hline $\mathrm{Fe}$ & $55 \cdot 4$ & $52 \cdot 0$ & $66 \cdot 1$ & $63 \cdot 8$ & $73 \cdot 9$ & $74 \cdot 7$ & $71 \cdot 4$ & $75 \cdot 7$ & 15 \\
\hline B & $15 \cdot 8$ & $12 \cdot 4$ & $20 \cdot 6$ & $19 \cdot 5$ & $14 \cdot 4$ & $10 \cdot 8$ & $18 \cdot 8$ & $19 \cdot 1$ & \\
\hline Mo & - & - & - & - & 0.9 & $1 \cdot 0$ & $0 \cdot 8$ & 0.7 & \\
\hline $\mathrm{Cr}$ & - & - & - & - & $0 \cdot 2$ & $0 \cdot 2$ & $0 \cdot 21$ & $0 \cdot 2$ & \\
\hline
\end{tabular}

*Nutrient requirement recommendations for a dairy Holstein cow with a milk production of $35 \mathrm{~kg} \mathrm{~d}^{-1}$ (NRC, 2001). 
Forage legumes had greater $\mathrm{N}$ concentration than herbs and grasses, which was because of their strong symbiotic $\mathrm{N}_{2}$ fixation, and which was measured for the four legumes grown in the same mixture in plots adjacent to the sampled plots of this study (data not shown). Increased $\mathrm{N}$ concentrations in herbs and grasses at the third cut compared with the first cut can be explained by a general increase in mineral concentrations during the growing season (Whitehead, 2000). Legumes need Mo for the symbiotic $\mathrm{N}_{2}$ fixation process because it is a constituent of the nitrogenase enzyme, which facilitates $\mathrm{N}_{2}$ fixation in root nodules (Whitehead, 2000). Mo accumulation in roots but not in shoots can explain our results that did not show greater Mo concentrations in legumes compared with grasses and herbs.

The role of $\mathrm{B}$ as a micromineral with important metabolic functions in animals is slowly being recognized (Goldbach and Wimmer, 2007). In the current study, herbs had greater B concentrations than legumes or grasses. Thus, herbs could be a key source of B for grazing animals.

Hopkins et al. (1994) demonstrated that mineral concentrations in total herbage vary during the season. In our study, herbs and grasses often showed similar mineral concentrations as legumes at the first cut, but they contained greater mineral concentrations than legumes at the third cut. This suggests that within the environmental and management conditions of this study, grasses, legumes and herbs can complement each other in terms of mineral concentrations at different times of the year.

\section{Slurry application and mineral concentrations}

The small effect of slurry application on the plant mineral composition is in agreement with Adams (1978) who reported that K and P applied via slurry had only a weak effect on plant mineral concentrations compared with inorganic fertilizer. Organically bound minerals in slurry can be the cause for this discrepancy because their uptake is generally slower and more difficult than for simple ions (Whitehead, 2000). Nonetheless, slurry application decreased the dry-matter proportion of legumes, which were rich in $\mathrm{Ca}, \mathrm{S}, \mathrm{Cu}$ and $\mathrm{B}$, and increased the proportion of the relatively 'mineral-poor' grasses (Table 3). This proportional change may have been the cause of lower $\mathrm{Ca}, \mathrm{S}, \mathrm{Cu}$ and $\mathrm{B}$ mineral concentrations in total herbage from the $200 \mathrm{~N}$ plots compared with 0N plots (Table 5). Belesky et al. (2001) also suggest that $\mathrm{N}$ application has an indirect effect on mineral concentrations by altering botanical composition of grassland with different $\mathrm{N}$ rates. Furthermore, the fact that the crop rotation at this site historically always received cattle manure on all plots may have resulted in the unfertilized plots in this study having greater soil mineral levels than would have been the case had they been unfertilized permanently.

\section{Minerals in a multi-species mixture vs. monocultures}

The grass-legume-herb mixture used in this study was a botanically diverse temporary grassland mixture that would not be commonly used in practice. Farmers, however, may sporadically include selected herbs in their forage seed mixtures (Smidt and Brimer, 2005). The mineral analysis of the total herbage showed that the multi-species mixture provided herbage of high nutritive value in terms of the concentrations of $\mathrm{K}, \mathrm{Mg}$, $\mathrm{Ca}, \mathrm{Mn}$ and Fe levels, as these were generally above the nutrient requirement values of a Holstein dairy cow producing $35 \mathrm{~kg}$ of milk per day (Table 5). However, $\mathrm{P}$ and $S$ concentrations were below the required values at some cuts (Table 5), and $\mathrm{Na}, \mathrm{Zn}$ and $\mathrm{Cu}$ levels were below the required values at all cuts (Table 5). This indicates that ruminants fed mainly on forage from grassland can receive a greater amount of their mineral requirements when the forage originates from a grasslegume-herb mixture compared with a grass monoculture and that this can reduce the need of mineral supplementation to animals. However, the mineral requirements of ruminants vary, and strategies for optimizing the mineral content of the total diet in organic dairy farming are under development (Mogensen et al., 2008).

The complexity of grassland management increases as the complexity of plant species diversity increases from grass monocultures to grass-legume mixtures and to grass-legume-herb mixtures (Sanderson et al., 2004). A recent study showed that increased functional grassland plant diversity increased root abundance (Mommer et al., 2010). Because root abundance can be positively related to soil mineral uptake (Mengel and Steffens, 1985; Kristensen and Thorup-Kristensen, 2004), we suggest that the multi-species mixture used in this study may have greater mineral uptake than monocultures. However, more studies are needed to shed light on plant interactions in a multi-species mixture and their effect on plant mineral concentrations.

It can be a challenge to produce good-quality forage from a grass-legume-herb mixture because other factors in addition to mineral content and productivity that affect intake have to be considered when deciding on the composition of a multi-species mixture. Nonetheless, increased functional and plant species diversity can improve the grassland ecosystem and provide other ecosystem services such as enhanced natural habitat for pollinators (Ebeling et al., 2008; Batary et al., 2010). 


\section{Conclusions}

Our study showed that, in general, the forage herbs included in the seed mixture provided herbage with greater concentrations of most macrominerals and some microminerals than that of grasses and forage legumes. Mineral concentrations in the three functional groups differed between the first and third cuts. Several minerals increased in herbs and grasses from the first to the third cut of each season, while mineral concentrations in legumes remained constant. Slurry application generally had no effect on the mineral composition of the functional groups but changed the botanical composition of the grass-legume-herb mixture, and consequently indirectly influenced mineral concentrations in the total herbage.

\section{Acknowledgments}

We thank Bente Broeng and Britta Garly Henriksen for helping with the mineral analysis and workers from the Research Farm Foulumgaard for practical support. We are indebted to the International Centre for Research in Organic Food Systems (ICROFS), who sponsored this research project.

\section{References}

Ad ams S.N. (1978) Response of pastures in Northern Ireland to $\mathrm{N}$-fertilizers, P-fertilizers and $\mathrm{K}$-fertilizers and to animal slurries. 2. Effects of mineral composition. Journal of Agricultural Science, Cambridge, 81, 419-428.

AskegaArd M., Eriksen J. and Olesen J.E. (2003) Exchangeable potassium and potassium balances in organic crop rotations on a coarse sand. Soil Use and Management, 19, 96-103.

Batary P., Baldi A., Saropataki M., Kohler F., Verhulst J., Knop E., Herzog F. and Kleijn D. (2010) Effect of conservation management on bees and insectpollinated grassland plant communities in three European countries. Agriculture Ecosystems and Environment, 136, 35-39.

Belesky D.P., Turner K.E., Fedders J.M. and Ruckle J.M. (2001) Mineral composition of swards containing forage chicory. Agronomy Journal, 93, 468-475.

Casler M.D., Collins M. and Reich J.M. (1987) Location, year, maturity, and alfalfa competition effects on mineral element concentrations in smooth bromegrass. Agronomy Journal, 79, 774-778.

Danish Plant Directorate (2010) Vejledning om $ø$ kologisk jordbrugsproduktion (Guideline for organic agricultural production). Available at: http://pdir.fvm.dk/ Vejledning_om_oekologisk_jordbrugsproduktion. aspx?ID=2137.

Ebeling A., Klein A.M., Schumacher J., Weisser W.W. and Tscharntke T. (2008) How does plant richness affect pollinator richness and temporal stability of flower visits? Oikos, 117, 1808-1815.
European Commission (2006) Eurostat. Available at: http://epp.eurostat.ec.europa.eu/portal/page/portal/ agriculture/data/database.

European Commission (2010) Community register of feed additives. Available at: http://ec.europa.eu/food/ food/animalnutrition/feedadditives/ comm_register_feed_additives_1831-03.pdf.

Fisher G.E.J., BAKer L.J. and Tiley G.E.D. (1996) Herbage production from swards containing a range of grass, forb and clover species and under extensive management. Grass and Forage Science, 51, 58-72.

Foster L. (1988) Herbs in pastures - development and research in Britain, 1850-1984. Biological Agriculture and Horticulture, 5, 97-133.

Garcia-Ciudad A., Ruano-Ramos A., Dealdana B.R.V. and GARCIA-Criado B. (1997) Interannual variations of nutrient concentrations in botanical fractions from extensively managed grasslands. Animal Feed Science and Technology, 66, 257-269.

Gold bach H.E. and Wimmer M.A. (2007) Boron in plants and animals: is there a role beyond cell-wall structure? Journal of Plant Nutrition and Soil Science-Zeitschrift fur Pflanzenernahrung und Bodenkunde, 170, 39-48.

Hansen T.H., Laursen K.H., Persson D.P., Pedas P., Husted S. and Schjoerring J.K. (2009) Micro-scaled high-throughput digestion of plant tissue samples for multi-elemental analysis. Plant Methods, 5, 1-11.

HAYNES R.J. (1980) Ion-exchange properties of roots and ionic interactions within the root apoplasm - their role in ion accumulation by plants. Botanical Review, 46, 7599.

Høgh-Jensen H., Nielsen B. and Thamsborg S.M. (2006) Productivity and quality, competition and facilitation of chicory in ryegrass/legume-based pastures under various nitrogen supply levels. European Journal of Agronomy, 24, 247-256.

Hopkins A., Adamson A.H. and Bowling P.J. (1994) Response of permanent and reseeded grassland to fertilizer nitrogen. 2. Effects on concentrations of $\mathrm{Ca}, \mathrm{Mg}$, $\mathrm{K}, \mathrm{Na}, \mathrm{S}, \mathrm{P}, \mathrm{Mn}, \mathrm{Zn}, \mathrm{Cu}$, Co and $\mathrm{Mo}$ in herbage at a range of sites. Grass and Forage Science, 49, 9-20.

Husted S., Mikkelsen B.F., Jensen J. and Nielsen N.E. (2004) Elemental fingerprint analysis of barley (Hordeum vulgare) using inductively coupled plasma mass spectrometry, isotope-ratio mass spectrometry, and multivariate statistics. Analytical and bioanalytical chemistry, 378, 171-182.

IFOAM (2005) The principles of organic agriculture. Available at: http://www.ifoam.org/about_ifoam/ principles/index.html.

Kabata-Pendias A. and Pendias H. (2000) Trace elements in soils and plants. Boca Raton, FL, USA: CRC Press.

Kristensen H.L. and Thorup-Kristensen K. (2004) Root growth and nitrate uptake of three different catch crops in deep soil layers. Soil Science Society of America Journal, 68, 529-537.

Kuusela E. (2006) Annual and seasonal changes in mineral contents ( $\mathrm{Ca}, \mathrm{Mg}, \mathrm{P}, \mathrm{K}$ and $\mathrm{Na}$ ) of grazed clovergrass mixtures in organic farming. Agricultural and Food Science, 15, 23-34. 
MARSCHNer H. (1995) Mineral nutrition of higher plants. London, UK: Academic Press.

Mengel K. and Steffens D. (1985) Potassium uptake of rye-grass (Lolium perenne) and red clover (Trifolium pratense) as related to root parameters. Biology and Fertility of Soils, 1, 53-58.

MøвеRg J.P. and Dissing N.J. (1986) The constituent composition of soils from Danish State Agricultural Research Stations. Report no. S 1870. Tjele, Denmark: Danish Institute of Plant and Soil Science.

Mogensen L., Kristensen T., Søegaard K. and Jensen S.K. (2008) How can the organic farmer be self-sufficient with vitamins and minerals. In: Neuhoff D., Halberg N., Alföldi T., Lockeretz W., Thommen A., Rasmussen I., Hermansen J., Vaarst M., Lueck L., Caporali F., Jensen H.H., Migliorini P. and Willer H. (eds), Cultivating the future based on science, pp. 152-155. Modena, Italy: Proceedings of the Second Scientific Conference of the International Society of Organic Agriculture Research (ISOFAR).

Mommer L., Van Ruijven J., De Caluwe H., SmitTiekstra A.E., Wagemaker C.A.M., Ouborg N.J., Bogemann G.M., Van Der Weerden G.M., Berendse F. and De Kroon H. (2010) Unveiling below-ground species abundance in a biodiversity experiment: a test of vertical niche differentiation among grassland species. Journal of Ecology, 98, 1117-1127.

National Research Council (2001) Nutrient requirements of dairy cattle. Washington D.C., USA: National Academy Press.

R Development Core Team (2010) R: A language and environment for statistical computing. Available at: http://www.R-project.org.

Sanderson M.A., Labreveux M., Hall M.H. and ELWINGER G.F. (2003) Nutritive value of chicory and English plantain forage. Crop Science, 43, 17971804.

SAnderson M.A., Skinner R.H., Barker D.J., Edwards G.R., Tracy B.F. and Wedin D.A. (2004) Plant species diversity and management of temperate forage and grazing land ecosystems. Crop Science, 44, 11321144.

Smidt N.W. and Brimer L. (2005) The use of herbs in pastures: an interview survey among bio-dynamic and organic farmers with dairy cattle. Agriculture and Human Values, 22, 355-363.

Soder K.J. and Stout W.L. (2003) Effect of soil type and fertilization level on mineral concentration of pasture: potential relationships to ruminant performance and health. Journal of Animal Science, 81, 1603-1610.

Soil Survey Staff (1998) Ultisols. In: Soil Survey Staff (ed.) Keys to Soil Taxonomy, pp. 267-269. Washington DC: United States Department of Agriculture, Natural Resources Conservation Service.

Underwood E.J. and Suttle N.F. (1999) The mineral nutrition of livestock. Wallingford, UK: CABI Publishing.

Weller R.F. and Bowling P.J. (2007) The importance of nutrient balance, cropping strategy and quality of dairy cow diets in sustainable organic systems. Journal of the Science of Food and Agriculture, 87, 2768-2773.

Whitehead D.C. (2000) Nutrient elements in grassland: soilplant-animal relationships. Wallingford, UK: CABI Publishing.

Wilman D. and Derrick R.W. (1994) Concentration and availability to sheep of $\mathrm{N}, \mathrm{P}, \mathrm{K}, \mathrm{Ca}, \mathrm{Mg}$ and $\mathrm{Na}$ in chickweed, dandelion, dock, ribwort and spurrey, compared with perennial ryegrass. Journal of Agricultural Science, Cambridge, 122, 217-223. 